\section{Nauplius}

The Journal OF The Brazilian Crustacean Society

\author{
e-ISSN 2358-2936 \\ www.scielo.br/nau \\ www.crustacea.org.br
}

\title{
First record of Oithona attenuata Farran, 1913 (Crustacea: Copepoda) from Brazil
}

Judson da Cruz Lopes da Rosa' (1) orcid.org/0000-0001-7635-8736

Wanda Maria Monteiro-Ribas² (10 orcid.org/0000-0002-1228-2805

Lucas Lemos Batista ${ }^{3}$ (1) orcid.org/0000-0003-2389-7132

Lohengrin Dias de Almeida Fernandes ${ }^{2}$ (1) orcid.org/0000-0002-8579-2363
1 Programa de Pós-Graduação em Ciências Ambientais e Conservação, Laboratório Integrado de Zoologia na Universidade Federal do Rio de Janeiro. Macaé, Rio de Janeiro, Brasil.
2 Instituto de Estudos do Mar Almirante Paulo Moreira, Departamento de Oceanografia, Divisão de Ecossistemas Marinhos. Arraial do Cabo, Rio de Janeiro, Brasil.
3 Instituto de Biodiversidade e Sustentabilidade (NUPEM/UFRJ), Laboratório Integrado de Zoologia na Universidade Federal do Rio de Janeiro. Macaé, Rio de Janeiro, Brasil.

ZOOBANK: http://zoobank.org/urn:lsid:zoobank.org:pub:5761ED4C-A9E3-4A61AB50-6537E7F192C1

\section{Abstract}

Here, we report the first record of the marine copepod Oithona attenuata Farran, 1913, in Brazil, from a costal station near Cabo Frio Island, Arraial do Cabo Municipality, Rio de Janeiro State. Specimens were found during March and May 2011 in zooplankton samples obtained from horizontal hauls using a plankton-net with a $100 \mu \mathrm{m}$ mesh size, and mouth opening of $40 \mathrm{~cm}$ diameter.

\section{KEYWORDS}

Arraial do Cabo, Cyclopoida, geographic distribution, microcrustaceans, zooplankton

The order Cyclopoida consists of 44 families of mostly holoplanktonic species (Boxshall and Halsey, 2004), of which numerous members have been shown to be good indicators of the physical-chemical characteristics of water (Boltovskoy, 1981; Nishida, 1985; Dias and Araujo, 2006). Of these families,

CORRESPONDING AUTHOR Judson da Cruz Lopes da Rosa judsoncruz@yahoo.com.br

SUBMITTED 26 February 2018 ACCEPTED 26 December 2018 PUBLISHED 28 March 2019

DOI 10.1590/2358-2936e2019001

\section{(cc) BY}

All content of the journal, except where identified, is licensed under a Creative Commons attribution-type BY.

Nauplius, 27: e2019001 the Oithonidae Dana, 1853 stand out in terms of their occurrence frequency and abundance in the South Atlantic, particularly species of the genus Oithona Baird, 1843. The following species are known to occur along the Brazilian coast (Razouls et al., 2018): Oithona amazonica Burckhardt, 1913, Oithona atlantica Farran, 1908, Oithona bjornbergae Ferrari and Bowman, 1980, Oithona bowmani Rocha, 1986, Oithona fallax Farran, 1913, Oithona frigida Giesbrecht, 1902, Oithona gessneri Kiefer, 1954, Oithona oligohalina 
Fonseca and Björnberg, 1976, Oithona linearis Giesbrecht, 1891, Oithona nana Giesbrecht, 1893, Oithona plumifera Baird, 1843, Oithona pseudofrigida Rosendorn, 1917, Oithona robusta Giesbrecht, 1891, Oithona sapucaiae Oliveira, 1945, Oithona setigera (Dana, 1849), Oithona similis Claus, 1866, Oithona simplex Farran, 1913, and Oithona tenuis Rosendorn, 1917. Different species of Oithona show different levels of adaptability to physical and hydrological parameters (Nishida, 1985) and include cosmopolitan species as well as those with narrower distribution ranges. They comprise both neritic and oceanic species that feed on smaller-sized organisms, such as heterotrophic and autotrophic protists and copepod nauplii (Yahia et al., 2004). In turn, they are the more important food for fish larvae and other zooplanktivorous. Oithonids, therefore, may play a more important role in the transfer of both bacterial and algal carbon to higher trophic levels than previously thought (Hwang et al., 2010). The species Oithona attenuata Farran, 1913 occurs only in the Southern Hemisphere, but has not yet been recorded on the Brazilian coast. However, this species has already been recorded in places of resurgence such as South Africa (Razouls et al., 2018). In this present work we report the first record of $O$. attenuata in regions of upwelling currents in Brazil.
Weekly zooplankton samples were obtained for over three years (2010-2012) in Arraial do Cabo Municipality, Rio de Janeiro State, Brazil in a horizontal haul (3 min, 1 m depth) using a $100 \mu \mathrm{m}$ mesh $40 \mathrm{~cm}$ diameter WP2 plankton net in water of about $10 \mathrm{~m}$ deep (Fig. 1). Immediately after collection, samples were fixed in a $4 \%$ formalin solution diluted with seawater and previously buffered with sodium tetraborate. Copepod abundance (ind. $\mathrm{m}^{-3}$ ) was estimated from three sub-samples taken with a modified Stempel pipette $(2.68 \mathrm{ml})$ to a lower limit of 100 individuals (Frontier, 1981). Immediately after the hauls, water temperature (SST) was measured using a reverse thermometer mounted on the Nansen bottle and salinity using a Guildline salinometer. Copepods sorted from samples were identified and measured under a Zeiss Stemi SV6 stereo microscope. Measurements were taken with Zeiss Zen ${ }^{\circledR}$ software from pictures taken in petri dishes. The World Register of Marine Species - WoRMS website (http://www. marinespecies.org) was used to confirm the current species names. The entire field and laboratory procedure was performed with the assistance of the Instituto de Estudos do Mar Almirante Moreira (IEAPM). More details of the copepod assemblage can be found in the work by Rosa et al. (2016).

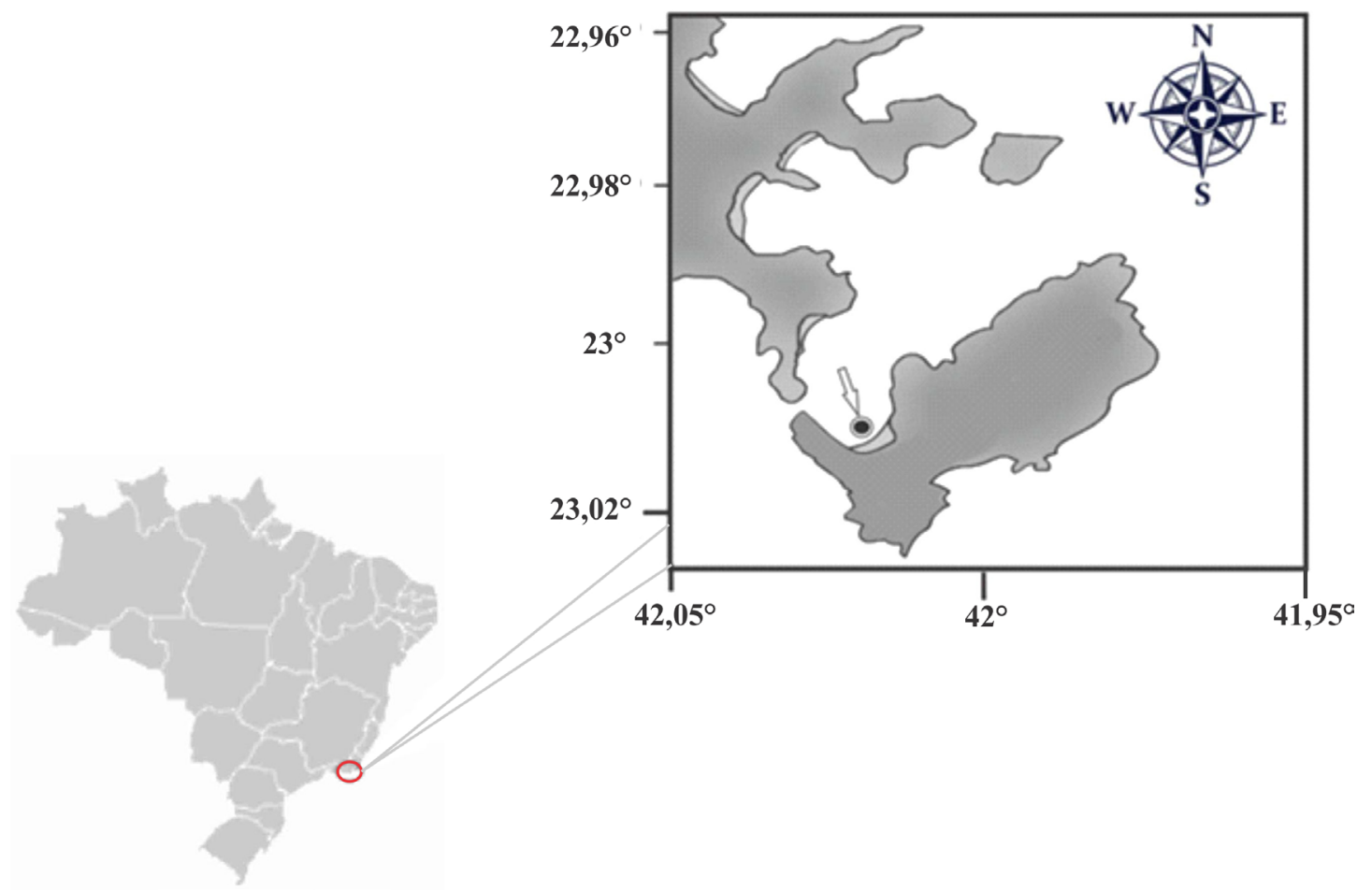

Figure 1. Map of the geographic location of Arraial do Cabo, state of Rio de Janeiro, Brazil. 
The temperature and salinity at the sampling site off Cabo Frio Island (22 59 ' $86^{\prime}$ 'S, $42^{\circ} 00^{\prime} 28^{\prime}$ W) were approximately $24.4^{\circ} \mathrm{C}$ and $35.9 \mathrm{psu}$, respectively, at the end of the austral summer (March) and approximately $24.5^{\circ} \mathrm{C}$ and 34.5 psu in autumn (May). The mean copepod abundance ranged between 92 and 125 ind. $\mathrm{m}^{-3}$ with higher densities found in more saline waters. In contrast, lower densities of copepods were found in less saline waters and constituted $17 \%$ of the
Oithonidae collected over the two days of sampling. Over three years of monitoring, 6 individuals of $O$. attenuata were found in only two months: March and May 2011 (Fig. 2). Oithonidae species registered over the years include $O$. simplex, $O$. oligohalina, $O$. plumifera, and O. setigera. The size of O. attenuata females varied between 0.63 and $0.62 \mathrm{~mm}$ (prosoma 0.28 and $0.29 \mathrm{~mm}$; depth the prosoma $0.12-0.14$; urosoma $0.32-0.34 \mathrm{~mm}$ ).
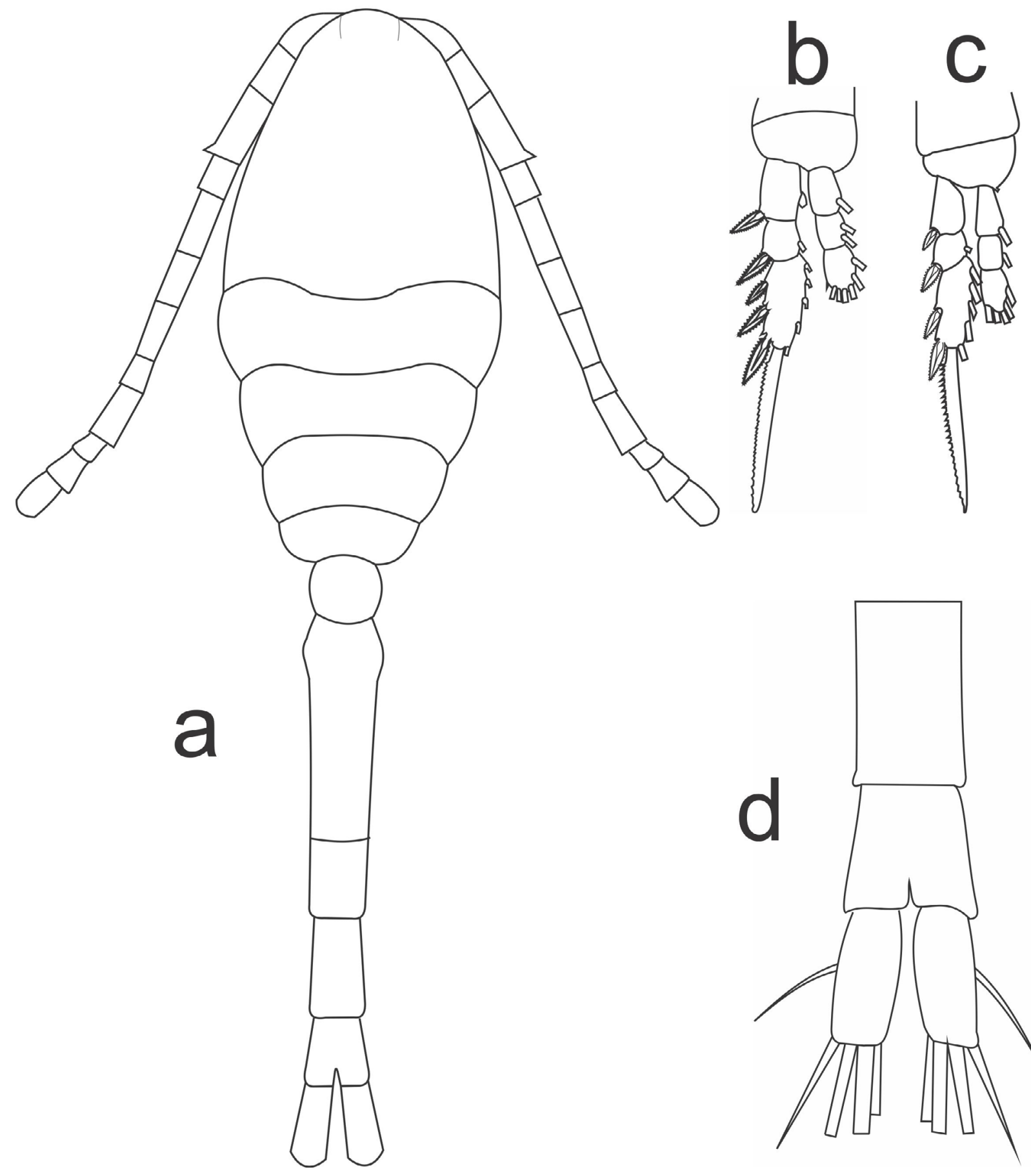

Figure 2. Oithona attenuata Farran, 1913. a, Whole body, dorsal view; b, leg 3; c, leg 4; d, furca. 
Oithona attenuata is an epipelagic species most commonly found in the Mediterranean Sea (Lebanon Basin), Red Sea, Gulf of Oman, Arabian Sea and Arabian Gulf. It is also found throughout the Indian and tropical Pacific (W \& central) oceans. More specifically, this includes: out off South Africa (Cape of Good Hope, Eastern side), the Maldives, Madagascar (Nosy Bé), Seychelles, Nicobar Is., Christmas Is., Straits of Malacca, Indonesia-Malaysia, Samoa (Pago Pago Harbour), China (Yellow Sea, East China Sea, South China Sea), Pa-Li, Taiwan (E, S, SW, W, NE, Tapong Bay, Danshuei Estuary), South Korea, Japan, Palau, W Baja California (Bahia Magdalena), Australia (Melbourne, Great Barrier, Exmouth Gulf, North West Cape, G. of Carpentaria) and Chile (Razouls et al., 2018).

Diagnosis of O. attenuata: Swimming legs (P1) exopodite and endopodite 3-segmentend; caudal rami (CR) with 6 plumose setae; swimming legs (P1-P4) exopodite outer spine formula otherwise arranged (Oithona). Forehead not produced into pointed rostrum (R). Swimming legs (P4) exopodite 3 with 2 outer spines. Free segment of swimming legs (P5) with only 1 terminal seta or 1 terminal seta and 1 marginal spinule. Mandible B with 1 strong spinulose spine and 1 fine seta on distal end. Maxillule 1 endopod with 4 setae; maxillule $(\mathrm{Mx}) 1$ lobe 1 distal marginal setae about twice longer than other setae. Caudal rami (CR) about 4 times longer than wide. The sister species $O$. nana has the following characteristics: Caudal rami (CR) 20-27 times longer than wide; maxillule 1, maxilla 2 , endites (Li1) with marginal distal seta similar in length to other setae.

Oithona attenuata is recorded here for the first time off Brazil, even though several studies had previously been conducted in the same place (Valentin, 1984; Dias and Araujo, 2006; Dias et al., 2010; Rosa and Monteiro-Ribas, 2012; Rosa et al., 2016). Its absence in plankton samples over the last 30 years leads us to suggest that this species was brought to Brazilian waters as an exotic species. The study site is close (less than two miles) to the Arraial do Cabo harbor, where foreign ships rarely discharge ballast water. The potential of $O$. attenuata to become an introduced species depends upon its resilience and ability to adapt to the new environment (Villac et al., 2009). In other words, it'd have to be some advantage in feeding or reproduction over native species that have similar environmental requirements, namely Dioithona oculata (Farran, 1913), O. nana, O. oligohalina and Oithona simplex quinquesetosa Früchtl, 1923 among others (Razouls et al., 2018), to be successfully introduced. Exotic copepods that have been successfully introduced off the Brazilian coast include: Temora turbinata (Dana, 1849), Pseudodiaptomus trihamatus Wright, 1937, Apocyclops borneoensis Lindberg, 1954, Paracyclopina longifurca (Sewell, 1924), Phyllopodopsyllus setouchiensis Kitazima, 1981. Furthermore, another exotic species, Pontella marplatensis Ramirez, 1966 (Pontellidae), was also recorded for the first time in the same region off Arraial do Cabo in September 2010 (Rosa and Monteiro-Ribas, 2012). It was described from the Argentine Sea (Mar del Plata) by Ramirez (1966) and had since also been found off Texas (Gulf of Mexico) (Waggett and Buskey, 2008). There is a hypothesis that $O$. attenuata may have come from the Indian Ocean from a whirlwind and arriving in Brazil, because according to Villar et al. (2015) plankton can be transported in this way. The absence of more individuals in samples collected during ongoing monitoring in the following months lead us to conclude that $O$. attenuata did not successfully reach the status of an introduced species. Since little is known about the rate of introduction, as more exotic species are recorded in the literature, the more confident our results in addressing the risk of unintended introductions off the Brazilian Coast will be.

\section{ACKNOWLEDGEMENTS}

We thankFAPERJ - Fundação Carlos Chagas Filho de Amparo à Pesquisa do Estado do Rio de Janeiro for their financial support (E26/110.220/2011), training scholarship and technical training (enrollment - 2011.3807.5).

\section{References}

Baird, W. 1843. Note on the luminous appearance of the sea, with descriptions of some of the entomostracous insects by which it is occasioned. Zoologist, 2: 55-61.

Boltovskoy, D.C. 1981. Atlas del zooplancton del Atlántico Sudoccidental y métodos de trabajo con el zooplancton marino. Argentina, INIDEP, 587-677.

Boxshall, G.A. and Halsey, S. 2004. An introduction to copepod diversity. London, The Ray Society, 966p.

Burckhardt, G. 1913. Wissenschaftliche Ergebnisse einer Reise um die Erde von M. Pernod und C. Schröter. III. Zooplankton 
aus ost- und süd-asiatische Binnengewässern. Zoologische Jahrbücher. Abteilung für Systematik, Geographie und Biologie der Tiere, 34: 341-472.

Claus, C. 1866. Die Copepoden-Fauna von Nizza. Sohr. Ges. Belford. ges. Nature, 7: 1-34.

Dana, J.D. 1849. Conspectus Crustaceorum, in Orbis Terrarium Circumnvigatione, C. Wilkes E Classe Reipublicae Foederatae Duce Collectorum. Proceedings of the American Academy of Arts and Sciences, 2: 9-61.

Dana, J.D. 1853. Crustacea. Part II. In: United States Exploring Expedition. During the years 1838, 1839, 1840, 1841, 1842. Under the command of Charles Wilkes. U. S. N. C. Philadelphia, Sherman, 14: 689-1618.

Dias, C.O. and Araujo, A.V. 2006. Copepoda. In: S.L.C. Bonecker (ed), Atlas de zooplâncton da região central da zona econômica exclusiva brasileira. Rio de Janeiro, Museu Nacional, Série Livros/Documentos REVIZEE Score Central, 23-101.

Dias, C.O.; Araújo, A.V.; Paranhos, R. and Bonecker, S.L.C. 2010. Vertical copepod assemblages $(0-2300 \mathrm{M})$ off southern Brazil. Zoological Studies, 49: 230-42.

Farran, G.P. 1908. Note on the copepod genus Oithona. The Annals and magazine of natural history, 2: 498-503.

Farran, G.P. 1913. Plankton from Christmas Island, Indian Ocean. II. On Copepoda of the genera Oithona and Paroithona. Proceedings of the Zoological Society of London, 2823: 181-93.

Ferrari, F.D. and Bowman, T.E. 1980. Pelagic copepods of the family Oithonidae (Cyclopoida) from the East Coasts of Central and South America. Smithsonian Contributions to Zoology, 312: 1-27.

Fonseca, V.L. and Bjürnberg, T.K.S. 1976. Oithona oligalina, sp. n. de Cananéia (Est. de São Paulo) e considerações sobre Oithona ovalis Herbst (Copepoda, Cyclopoida). Anais da Academia Brasileira de Ciências, 47: 127-131.

Frontier, S. 1981. Diseño de muestreos. In: D. Boltovskoy (ed), Atlas del zooplancton del Atlántico Sudoccidental y métodos de trabajo con el zooplancton marino. Mar del Plata, Argentina, INIDEP, 103-108.

Friichtl, F. 1923. Cladoceren und Copepoden der Aru-Inseln (vorlaufige Mitteilung: Artenliste und Kurze Diagnosen der neuen Formen). Abhandlungen der Senckenbergischen Naturforschenden Gesellschaft, 37: 449-457.

Giesbrecht, W. 1891. Elenco dei copepodi pelagici raccolti dal tenente di vascello Gaetano Chierchia durante il viaggio della R. Corvetta 'Vettor Pisani' negli anni 1882-1885 E dal tenente di vascello Francesco Orsini nel Mar Rosso, nel 1884. Rendiconti Delle Sedute Della R. Accademia dei Lincei, 4: 474-481.

Giesbrecht, W. 1893. Systematik und Faunistik der pelagischen Copepoden des Golfes von Neapel und der angrenzenden Meeres-Abschnitte. Fauna und Flora des Golfes von Neapel und der Angrenzenden Meeres-Abschnitte. Herausgegeben von der Zoologischen Station zu Neapel, 19: 1-831, pls. 1-54.

Giesbrecht, W. 1902. Résultats du voyage du S.Y. Belgica en 1898-1899. Copepoden Rapp acient Govt beige. Zoologist, 1902: 1-49.

Hwang, J.S.; Kumar, R.; Dahms, H.U.; Tseng, L.C and Chen, Q-C. 2010. Interannual, seasonal, and diurnal variations in vertical and horizontal distribution patterns of 6 Oithona spp.
(Copepoda: Cyclopoida) in the South China Sea. Zoological Studies, 49: 220-229.

Kiefer, F. 1954. Drei neue Ruderfusskrebse (Crust. Cop.) aus Venezuela. Zoologischer Anzeiger, 3: 170-174.

Kitazima, Y. 1981. Three new species of the genus Phyllopodopsyllus (Copepoda, Harpacticoida) from the Inland Sea of Japan. Publications of the Seto Marine Biological Laboratory, 26: 393-424.

Lindberg, K. 1954. Cyclopides (Crustacés copépodes) de l'Amerique du Sud. Arkiv för Zoologi, 7: 193-222.

Nishida, S. 1985. Taxonomy and distribution of the family Oithonidae (Copepoda, Cyclopoida) in the Pacific and Indian oceans. Bulletin Ocean Research Institute University, 20: $1-167$.

Oliveira, L.P.H. 1945. Contribuição ao conhecimento dos crustáceos do Rio de Janeiro: Ordem Eucopepoda. Memorias do Instituto Oswaldo Cruz, 42: 449-72.

Ramírez, F.C. 1966. Copépodos calanoideos marinos da área de Mar del Plata con la descripción de Pontella marplatensis $\mathrm{n}$. sp. Boletín Instituto de Biología Marina, 11: 1-24.

Razouls, C.; Bovée, F.; Kouwenberg, J. and Desreumaux, N. 2018. Diversity and geographic distribution of marine planktonic copepods. Available at: http://copepodes.obs-banyuls.fr/ en/index.php. Accessed on 05 February 2018.

Rocha, C.E.F. 1986. Copepods of the genus Oithona Baird, 1843 from mangrove areas of Central and South America. Hydrobiologia, 135: 95-107.

Rosa, J.C.L. and Monteiro-Ribas, W.M. 2012. Ocurrence record of Pontella marplatensis copepod in Arraial do Cabo RJ - Brazil. Biotemas, 25: 197-98.

Rosa, J.C.L.; Monteiro-Ribas, W.M. and Fernandes, L.D.A. 2016. Herbivorous copepods with emphasis on dynamic Paracalanus quasimodo in an upwelling region. Brazilian Journal of Oceanography, 64: 67-74.

Rosendorn, I. 1917. Die Gattung Oithona. Wiss Ergebn Deutschen. Tiefsee-Expedition "Valdivia", 23: 1-58.

Sewell, R.B.S. 1924. Crustacea Copepoda: Fauna of Chilka Lake. Memoirs of the Indian Museum, 5: 771-851, pls. 44-59.

Valentin, J.L. 1984. Spatial structure of the zooplankton community in the Cabo Frio Region (Brazil) influenced by coastal upwelling. Hydrobiologia, 113: 183-99.

Villac, M.C.; Lopes, R.M.; Rivera, I.N.G.; Bassanello, R.T.; Cunha, D.R.; Martinelli-Filho, J.E. and Santos, D.B. 2009. Plâncton. In: R.M. Lopes (ed), Informe sobre as espécies exóticas invasoras marinhas no Brasil. Brasilia, MMA/SBF, 39-104.

Villar, E.; Farrant, G.K; Follows, M. et al. 2015. Environmental characteristics of Agulhas rings affect interocean plankton transport. Science, 348 (6237): 11p.

Waggett, J.R. and Buskey, J.E. 2008. Escape reaction performance of myelinated and non-myelinated calanoid copepods. Journal of Experimental Marine Biology and Ecology, 361: 111-118.

Wright, S. 1937. Two new species of Pseudodiaptomus. Anais da Academia Brasileira de Ciências, 9: 155-162.

Yahia, M.N.D.; Sami, S. and Yahia-Kefi, O.D. 2004. Spatial and temporal structure of planktonic copepods in the Bay of Tunis (Southwestern Mediterranean Sea). Zoological Studies, 43: $366-375$. 